\title{
Modified FOLFIRI-Bevacizumab Regimen in the Patients with Metastatic Colorectal Cancer Who Had Progressed After Oxaliplatin-Based Regimen
}

\author{
Oksaliplatin-Temelli Rejim Altında Progresyon Gösteren Metastatik Kolorektal Kanserli \\ Hastalarda Modifiye Folfiri-Bevasizumab Rejimi
}

\author{
Doğan Koca', Davut Demir², Oğuzhan Özdemir ${ }^{3}$, Hüseyin Akdeniz ${ }^{3}$, Mehmet Kurt ${ }^{3}$ \\ ${ }^{1}$ Van Speciality Istanbul Hospital, Department of Internal Diseases, Division of Medical Oncology; ${ }^{2}$ Department of Oncologic Surgery; \\ ${ }^{3}$ Department of Radiology, Van, Turkey
}

\begin{abstract}
Aim: We aimed to investigate the efficacy and tolerability of modified FOLFIRI-Bevacizumab (mFOLFIRI-B) regime in the secondline treatment of metastatic colorectal cancer $(m C R C)$ patients who received oxaliplatin-based regimen in the first-line treatment.

Material and Method: The patients treated with mFOLFIRI-B regimen in second-line therapy who had progressed after oxaliplatin-based chemotherapy were included in this study. The datas of toxicity and efficacy of the regimen were retrospectively evaluated.

Results: Total $172 \mathrm{mCRC}$ patients had received mFOLFIRI-B regime in the second-line treatment. $39.5 \%$ objective response rate, 9.0 months (7.6 to 10.3) median progression-free survival, 19.0 months (15.1 to 26.2) median overall survival were found. Grade $3 / 4$ toxicity was observed in $33.7 \%$. Grade $3 / 4$ hematologic toxicity was most frequently observed toxicity (31.9\%).

Conclusion: mFOLFIRI-B is an efficient and safe regimen for the second-line treatment of $m C R C$ patients after the oxaliplatinbased regimen.
\end{abstract}

Key words: metastatic colorectal cancer; second-line chemotherapy; modified FOLFIRI-Bevacizumab

\section{ÖZET}

Amaç: Illk-sıra tedavide oksaliplatin-temelli rejim alan metastatik kolorektal kanserli (mKRK) hastalarda ikinci-sıra tedavide modifiye FOLFIRI-Bevacizumab (mFOLFIRI-B) rejiminin etkinlik ve tolerabilitesi araștırıldı.

Materyal ve Metot: Çalıșmaya ilk-sıra tedavide oksaliplatin-temelli rejim alan, ardından progresyon gözlenen ve ikinci-sıra tedavide mFOLFIRI-B rejimi alan mKRK'li hastalar alındı. Toksisite ve etkinlik ile ilgili veriler retrospektif olarak değerlendirildi.

Doğan Koca, Özel İstanbul Hastanesi, Urartu 1. Sok., Van, Türkiye, Tel.05056899197Email.dogan.koca@deu.edu.tr

Geliş Tarihi: 01.05.2015 • Kabul Tarihi: 04.03.2017
Bulgular: Toplam 172 mKRK'li hasta ikinci-sıra tedavide mFOLFIRI-B rejimi almıștı. Hastaların \%39,5'inde objektif cevap, 9,0 aylık (7,6 ile 10,3 arası) median progresyonsuz yașam, 19,0 aylık (15,1 ile 26,2 arası) median tüm yașam saptandı. Grade 3/4 toksisite \%33,7 oranında tespit edildi. Grade 3/4 hematolojik toksisite $\% 31,9$ oranında tespit edildi.

Sonuç: Sonuç olarak mKRK'li hastalarda oksaliplatin-temelli rejim sonrası ikinci-sıra tedavide mFOLFIRI-B rejimi etkili ve güvenilir bir tedavi rejimidir.

Anahtar kelimeler: metastatik kolorektal kanser; ikinci-sıra kemoterapi rejimi; modifiye FOLFIRI-Bevacizumab rejimi

\section{Introduction}

Colorectal cancer is a widespread and fatal disease. While constituting approximately $10 \%$ of all cancers, it is the third commonest malignancy in both genders and is the third leading cause of death. It is responsible of $10 \%$ of deaths due to cancer ${ }^{1,2}$. The main method of therapy in colorectal cancers is surgical therapy. A part of stage II patients and stage III patients are given adjuvant chemotherapy (CT) following surgical treatment. In stage IV patients, the main treatment approach is systemic $\mathrm{CT}^{2-4}$. In rectal cancer, adjuvant or neoadjuvant chemoradiotherapy (CRT) is added in addition to these approaches 5 .

Metastatic colorectal cancer (mCRC) constitutes an important part of all colorectal cancers ${ }^{6}$. Survival time increases and symptoms related to the disease are controlled with use of $\mathrm{CT}^{7-9}$. Currently, survival time has increased to more then 2 years with new generation CT drugs including oxaliplatin and irinotecan and 
with addition of targeted drugs including bevacizum$a b$ and cetuximab ${ }^{10-14}$. In addition, survival rates have been shown to increase further with current efficient CT which renders unresectable metastases resectable and with performed of metastasectomy ${ }^{15-18}$.

In treatment of $\mathrm{mCRC}$, combination regimens based on 5-FU are still the main therapeutical options. FOLFOX and FOLFIRI regimens which are constituted by adding oxaliptalin and irinotecan to 5-FU and combination regimes formed by adding bevacizumab and cetuximab are the most frequently used regimens ${ }^{19-23}$.

Bevacizumab is a recombinant humanized monoclonal IgG1 antibody that selectively binds to vascular endothelial growth factor (VEGF) and inhibits its interaction with its receptor ${ }^{24}$. It has been shown that there is considerable advantage of PFS and OS by usage of 5-FU, leucovorin and irinotecan combination regimen in first line therapy of $\mathrm{mCRC}^{13,25-28}$. Nowadays, there is suggestion of combination of bevacizumab with 5-FU, leucovorin plus irinotekan or 5-FU, leucovorin plus oxaliplatin in the first-line therapy of mCRC patients ${ }^{29}$.

Generally, in patients with K-ras mutant tumor, combination of bevacizumab with FOLFIRI regimen in first line treatment of $\mathrm{mCRC}$ have been accepted as standard therapy. However there are very few reports in the literature about efficieny and toxicities of second-line modified FOLFIRI-Bevacizumab (mFOLFIRI-B) regimen in $\mathrm{mCRC}$ patients who had progressed after oxaliplatin-based chemotherapies. It has been shown that bevacizumab containing regimen is an effective therapy in first-line treatment of $\mathrm{mCRC}$ patients, therefore it seems to be diffucult to use bevacizumab containing regimens as second-line therapy in any prospective study.

For this reason, evaluating of efficieny and tolerability of mFOLFIRI-B regimen as a second-line therapy is an important topic. Thus the aim of our study is showing retrospectively the efficieny and adverse effects of second-line mFOLFIRI-B regimen in mCRC patients who had progressed after oxaliplatin-based chemotherapies.

\section{Material and Method}

\section{Patients}

Patients with a diagnosis of $\mathrm{mCRC}$ who showed progression under the first-line treatment with oxaliplatin-based regime and received mFOLFIRI-B regime as the second-line treatment between January 2004 and August 2013 were evaluated. The files of the patients were evaluated retrospectively and data about the efficiency of CT, toxicities and survival were obtained.

Patients with stage IV colorectal cancer according to American Joint Committee on Cancer's (AJCC) Cancer Staging 6th edition 2002 TNM grading system who showed progression under the first-line treatment with oxaliplatin-based regime in metastatic period and received $\mathrm{mFOLFIRI-B}$ regime as the second-line therapy were included in the study ${ }^{30}$.

\section{Treatment}

mFOLFIRI-B regime included folinic acid $400 \mathrm{mg} /$ $\mathrm{m}^{2}+5$-FU $400 \mathrm{mg} / \mathrm{m}^{2}$ bolus + 5-FU $2.400 \mathrm{mg} / \mathrm{m}^{2} 46$ hour infusion + irinotecan $180 \mathrm{mg} / \mathrm{m}^{2}+$ bevacizumab $5 \mathrm{mg} / \mathrm{kg}$ every 14 days. Modified FOLFOX6 regime included folinic acid $400 \mathrm{mg} / \mathrm{m}^{2}+5-\mathrm{FU} 400 \mathrm{mg} /$ $\mathrm{m}^{2}$ bolus +5 -FU $2400 \mathrm{mg} / \mathrm{m}^{2}$ as a 46 -hour infusion + oxaliplatin $85 \mathrm{mg} / \mathrm{m}^{2}$ given once in every 14 days. FOLFOX6 regime included folinic acid $400 \mathrm{mg} / \mathrm{m}^{2}+$ 5 -FU $400 \mathrm{mg} / \mathrm{m}^{2}$ bolus +5 -FU $2400 \mathrm{mg} / \mathrm{m}^{2}$ as a $46-$ hour infusion + oxaliplatin $100 \mathrm{mg} / \mathrm{m}^{2}$ given once in every 14 days. FOLFOX7 regime included folinic acid $400 \mathrm{mg} / \mathrm{m}^{2}+5$-FU $400 \mathrm{mg} / \mathrm{m}^{2}$ bolus + 5-FU 2.400 $\mathrm{mg} / \mathrm{m}^{2}$ 46-hour infusion + oxaliplatin $130 \mathrm{mg} / \mathrm{m}^{2}$ every 14 days. XELOX 4 regime included capecitabine $2000 \mathrm{mg} / \mathrm{m}^{2}$ given 2 weeks on 1 -week off regimen + oxaliplatin $85 \mathrm{mg} / \mathrm{m}^{2}$ every three weeks. XELOX7 regime included capecitabine $2000 \mathrm{mg} / \mathrm{m}^{2}$ given 2 weeks on 1-week off regimen + oxaliplatin $130 \mathrm{mg} / \mathrm{m}^{2}$ every three weeks.

\section{Response Evaluation}

Response was evaluated after every 6 cycles or after three months. Evaluation of response was done according to tumor response assessment criteria of the World Health Organization $^{31}$. Accordingly, disappearance of the tumor completely was considered as complete response (CR), regression of the target lesion with a rate of $50 \%$ or more was considered as partial response (PR), regression of the target lesion less than $50 \%$ or progression of the target lesion less than $25 \%$ was considered as stable disease (SD) and progression of $25 \%$ or more in the target lesion or observation of a new lesion was considered as progressive disease (PD). The total of CR and PR was evaluated as objective response rate (ORR). 
After 6 cycles CT or after three months, $50 \%$ or more reduction in serum carcinoembryonic antigen (CEA) level was considered as tumor marker response. Evaluation of toxicity was done according to National Cancer Institute-Common Toxicity Criteria Version $2.0^{32}$.

The time from the beginning of first cycle day 1 of second-line CT to development of progression or death from any reason was considered as progression-free survival (PFS). The time from the first cycle day 1 of second-line CT to last follow-up or death was considered as overall survival (OS).

Statistical analysis of the data was done using Statistical Package for Social Sciences for Windows (SPSS) Version 15.0 software. Independent group ratios were compared using the chi-square test. Kaplan-Meier method was used for analyses of PFS and OS. Two survival curves were compared using Log-rank Test. The statistical significance was considered as $\mathrm{p}<0.05$.

\section{Results}

\section{Patient Features}

A total of 172 patients were evaluated. The median age of the all patients was $57(18-81) .71(41.3 \%)$ patients were female and $101(58.7 \%)$ were male. 98 (56.9\%) patients had metastatic colon cancer (Table 1). FOLFOX7 as the first-line regimen was the most common received by patients (Table 2 ). There was no determined relationship between survival time and first-line CT regimen ( $\mathrm{p}=0.568)$.

The most commonly observed metastatic organ was the liver (Table 1). 63 (36.6\%) of the patients had their primary tumor operated before mFOLFIRI-B regimen was started (Table 2).

\section{Treatment Regimens}

The median number of cycles for mFOLFIRI-B regimen was 6 (4-18). After mFOLFIRI-B regime 15 (8.7\%) patients received fifth-line CT (Table 2).

\section{Efficiency}

ORR was obtained in 68 (39.5\%) patients, 11 (6.3\%) of these had CR and 57 (33.1\%) had PR. Median follow-up time was found to be 42 (7-154) months from the time of metastases was detected. Median follow-up time was $16(7-69)$ months from the time of beginning of day 1 of second-line treatment. Median PFS was 9.0 (7.6 to 10.3) months, median OS was 19.0 (15.1 to 26.2) months (Figure 1, 2). Serum level of CEA reduction was observed in 35 (20.3\%) patients who had a high level of serum CEA. Primary tumor resection was performed in $12(6.9 \%)$ of the patients and metastasectomy was performed in $14(8.1 \%)$ of the patients. Hepatic metastasectomy was most commonly performed (Table 3).

\section{Toxicity}

Grade 3/4 toxicity was observed in 58 (33.7\%) patients. Hematologic toxicity was the most commonly observed $(31.9 \%)$. The most common hematologic toxicity was found to be neutropenia (27.9\%). Hypertension and proteinuria which are significant side effects of bevacizumab, was found to be $6.4 \%$ and $4.0 \%$, respectively (Table 4).

\section{Discussion}

Colorectal cancer is the third leading cancer among all cancers. Approximately half of colorectal cancers are metastatic at the time of diagnosis or become metastatic and need treatment subsequently. Currently, median survival has increased to more than two years due to advances in CT drugs used in recent years. Adding of oxaliplatin or irinotecan to combination of $5 \mathrm{FU}$ and leucoverin is mostly accepted CT protocol in treatment of $\mathrm{mCRC}$. The another important point is deciding of second-line CT regimen after progression of following first-line therapy in $\mathrm{mCRC}$. It has been realized that by addition of bevacizumab, a monoclonal antibody the CT response rate has increased. Therefore bevacizumab mostly has been used in first-line CT which is critical point. But especially in patients who had progressed after oxaliplatin-based regimen, the rate of efficieny and tolerability of addition of bevacizumab to second-line CT is exactly not known. This situation same in patients with K-ras mutant tumor. Thus the data in adding bevacizumab to mFOLFIRI will become important. From the point of this reason, we aim to evalutate datas of mFOLFIRI-B as a second line therapy of 172 patients who had progressed after oxaliplatin-based CT.

Combination of 5-FU/leucovorin is the first important regimen that had been used in $\mathrm{mCRC}$ patients and by this regimen 5 years OS is below the $1 \%{ }^{33}$. Nowadays by applying modern CT regimens and metastasectomies, rate of 5 years OS is nearly equal to $30 \%{ }^{34}$. 
Table 1. General characteristics of the patients

\begin{tabular}{|c|c|c|}
\hline Character & & $\mathrm{n}(\%)$ \\
\hline \multicolumn{3}{|l|}{ Gender } \\
\hline \multicolumn{2}{|r|}{ Female } & $71(41.3)$ \\
\hline \multicolumn{2}{|r|}{ Male } & $101(58.7)$ \\
\hline \multicolumn{3}{|c|}{ Primary tumor localization } \\
\hline \multicolumn{2}{|r|}{ Colon } & $98(56.9)$ \\
\hline & Right & $26(15.1)$ \\
\hline & Middle & $28(16.2)$ \\
\hline & Left & $44(25.6)$ \\
\hline \multicolumn{2}{|r|}{ Rectum } & $74(43.1)$ \\
\hline & Upper & $22(12.8)$ \\
\hline & Middle & $23(13.4)$ \\
\hline & Lower & $29(16.9)$ \\
\hline \multicolumn{3}{|c|}{ Histopathology } \\
\hline \multicolumn{2}{|r|}{ Adenocarcinoma } & $148(86.1)$ \\
\hline \multicolumn{2}{|r|}{ Other } & $24(13.9)$ \\
\hline \multicolumn{3}{|c|}{ Metastatic organ } \\
\hline \multicolumn{2}{|r|}{ Liver } & $114(66.2)$ \\
\hline \multicolumn{3}{|c|}{$\begin{array}{l}\text { Findings indicating } \\
\text { intraabdominal tumor invasion }\end{array}$} \\
\hline \multicolumn{2}{|r|}{ Lung } & $43(25.0)$ \\
\hline \multicolumn{2}{|r|}{ Bone } & $19(11.0)$ \\
\hline \multirow{2}{*}{\multicolumn{3}{|c|}{$\begin{array}{l}\text { Supraclavicular lymph node } \\
\text { involvement }\end{array}$}} \\
\hline & & \\
\hline \multicolumn{2}{|r|}{ Spleen } & $3(1.7)$ \\
\hline \multicolumn{2}{|r|}{ Ovary } & $2(1.1)$ \\
\hline \multicolumn{2}{|r|}{ Metastasis in two organs } & $41(23.8)$ \\
\hline \multicolumn{2}{|r|}{ Metastasis in more than two } & $27(15.6)$ \\
\hline \multicolumn{3}{|c|}{ Serum CEA } \\
\hline \multicolumn{2}{|r|}{$5 \mathrm{ng} / \mathrm{mL}$ and higher } & $145(84.4)$ \\
\hline \multicolumn{2}{|r|}{ Lower than $5 \mathrm{ng} / \mathrm{mL}$} & 27 (15.6) \\
\hline
\end{tabular}

CEA, Carcinoembryonic antigen.

Table 2. Other characteristics of the patients

\begin{tabular}{lc}
\hline & $\mathrm{n}(\%)$ \\
\hline History of primary tumor operation & $63(36.6)$ \\
History of adjuvant CT & $34(19.7)$ \\
History of neoadjuvant CRT & $25(14.5)$ \\
History of adjuvant CRT & $6(3.4)$ \\
In first-line CT regimes & \\
\multicolumn{1}{c}{ Modified FOLFOX6 } & $19(11.1)$ \\
$\quad$ FOLFOX6 & $5(2.9)$ \\
$\quad$ FOLFOX7 & $117(68.0)$ \\
$\quad$ XELOX4 & $9(5.2)$ \\
XELOX7 & $22(12.8)$ \\
In second-line CT regime & $172(100.0)$ \\
Modified FOLFIRI-Bevasizumab & $172(100.0)$ \\
Fourth-line CT received patients & $75(43.6)$ \\
Fifth-line CT received patients & $34(19.7)$ \\
\hline
\end{tabular}

Table 3. Efficacy provided by the treatment administered

\begin{tabular}{|c|c|c|c|}
\hline & $\begin{array}{l}\text { Month } \\
(95 \% \mathrm{Cl})\end{array}$ & $\%$ & $\mathrm{n}(\%)$ \\
\hline Median PFS & $\begin{array}{c}9.0 \\
(7.6-10.3)\end{array}$ & & \\
\hline Median OS & $\begin{array}{c}19.0 \\
(15.1-26.2)\end{array}$ & & \\
\hline 1 year $0 \mathrm{~S}$ & & 69.0 & \\
\hline 3 years OS & & 25.0 & \\
\hline 5 years OS & & 13.5 & \\
\hline Complete response & & & $11(6.4)$ \\
\hline Partial response & & & $57(33.1)$ \\
\hline All response rates & & & 68 (39.5) \\
\hline Stable disease & & & $42(24.4)$ \\
\hline Progressive disease & & & $62(36.0)$ \\
\hline $\begin{array}{l}\text { Patients who had undergone } \\
\text { primary tumor resection }\end{array}$ & & & $12(6.9)$ \\
\hline R0 resection & & & $10(5.8)$ \\
\hline R1 resection & & & $2(1.1)$ \\
\hline $\begin{array}{l}\text { Patients who had undergone } \\
\text { metastasectomy }\end{array}$ & & & $14(8.1)$ \\
\hline R0 resection & & & $11(6.4)$ \\
\hline R1 resection & & & $3(1.7)$ \\
\hline Liver metastasectomy & & & $10(5.8)$ \\
\hline Peritonectomy & & & $5(2.9)$ \\
\hline Lung metastasectomy & & & $5(2.9)$ \\
\hline Splenectomy & & & $1(0.5)$ \\
\hline $\begin{array}{l}\text { Patients whose serum CEA levels } \\
\text { decreased }\end{array}$ & & & $38(22.0)$ \\
\hline $\begin{array}{l}\text { Patients whose serum CEA level } \\
\text { decreased below } 5 \mathrm{ng} / \mathrm{mL}\end{array}$ & & & $12(6.9)$ \\
\hline
\end{tabular}

Table 4. Side effects caused by treatment

\begin{tabular}{lccc}
\hline Characteristic & $\begin{array}{c}\text { Grade } 1 / 2 \text { side } \\
\text { effects } \mathrm{n}(\%)\end{array}$ & $\begin{array}{c}\text { Grade } 3 / 4 \text { side } \\
\text { effects } \mathrm{n}(\%)\end{array}$ & $\mathrm{n}(\%)$ \\
\hline All & $113(65.6)$ & $58(33.7)$ & \\
All hematological side effects & $98(56.9)$ & $55(31.9)$ & \\
Neutropenia & $65(37.7)$ & $48(27.9)$ & \\
Anemia & $52(30.2)$ & $23(13.3)$ & \\
Thrombocytopenia & $41(23.8)$ & $19(11.0)$ & \\
Nausea/vomiting & $44(25.6)$ & $32(18.6)$ & \\
Diarrhea & $29(16.9)$ & $18(10.4)$ & \\
Oral mucositis & $32(18.6)$ & $14(8.1)$ & \\
Hand foot syndrome & $17(9.8)$ & $8(4.6)$ & \\
Allergic reaction & $8(4.6)$ & $2(1.1)$ & \\
Neurotoxicity & $4(2.3)$ & $2(1.1)$ & \\
Hypertension & & & $7(6.4)$ \\
Proteinuria & & & $7(3.9)$ \\
Skin eruption & & & $4(2.3)$ \\
Gastrointestinal bleeding & & & $3(1.7)$ \\
Neutropenic fever & & & $2(1.1)$ \\
Deep vein thrombosis & & &
\end{tabular}




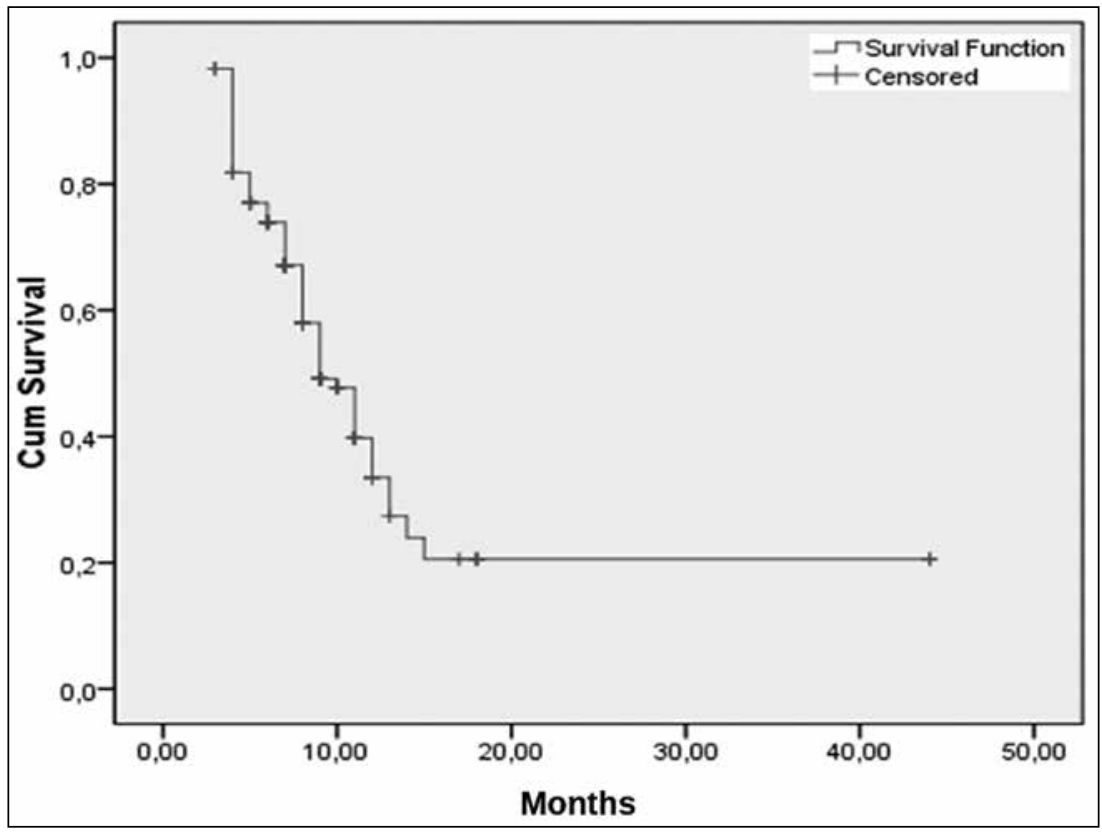

Figure 1. Progression-free survival (median 9.0 months).

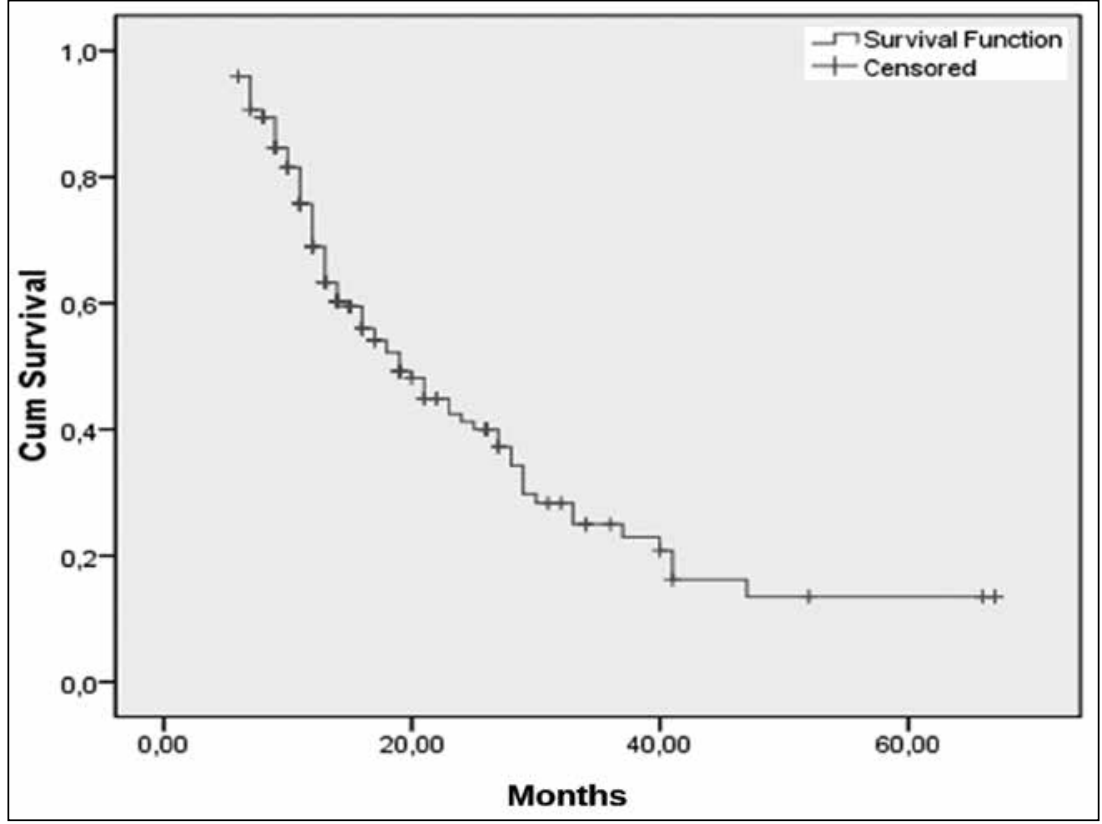

Figure 2. Overall survival (median 19.0 months).

Among the new chemotherapeutic agents, bevacizum$\mathrm{ab}$, a monoclonal antibody, is the first the drug that has been added to CT. By usage of bevacizumab in firstline therapy, survival has been getting quite longer. In a study that had used the combination of bevacizumab and irinotecan, bolus 5-FU-leucovorin (IFL regimen) in first-line therapy, by addition of bevacizumab to CT regimen, an important survival advantage has been achieved ${ }^{13}$. Infusional 5 -FU is more effective in mCRC. By the way it has been shown that FOLFIRI regimen is much more useful comparing to IFL regimen and another study showed that the addition of bevacizumab to FOLFIRI regimen had better PFS and OS results ${ }^{28,35}$. 
There are some studies that had used a bevacizumab containing regimen as second or third line therapy in mCRC patients that progressed after first-line therapy. Regarding this, there is an important study that used oxaliplatin, 5-FU, leucoverin and bevacizumab (FOLFOX4-B) as a second-line therapy after progression of patients with $\mathrm{mCRC}$. By this treatment option there was a advantage of $\mathrm{OS}^{36}$. As a result of showing effiency of bevacizumab in combination with oxaliplatin in second line therapy, a multicenter study using bevacizumab in combination with FOLFIRI regimen in second line treatment was performed. By this study, advantage of 8.3 months median PFS and 21.6 months median OS were achieved ${ }^{37}$.

Although bevacizumab has survival advantage in combination with first-line CT, it has been shown that after progression of disease there is still survival advantage of using bevacizumab in combination with second-line treatment ${ }^{38}$.

There is concensus about usage of bevacizumab in firstline therapy. It has not still being clearly defined that there is survival advantage of adding bevacizumab to mFOLFIRI regimen as a second-line therapy in patients who had previously used different CT regimens. Since mCRC patients are now huge populations, collecting data about mFOLFIRI-B as second-line therapy is becoming very important.

However, in our study, grade $3 / 4$ toxicity was observed in $33.7 \%$ of the patients. Grade 3/4 neutropenia was observed $27.9 \%$ of the patients. Side effects of bevacizumab, hypertension and proteinuria was found to be $6.4 \%$ and $4.0 \%$, respectively. This findings suggest that mFOLFIRI-B may be tolerated regimen for side effects.

Since this study was a retrospective study, it has disadvantages related to retrospective studies. However, regarding a subject like treatment of $\mathrm{mCRC}$ which concerns a large number of patients, we thought that it would be beneficial to present mFOLFIRI-B regime in the second-line treatment which showed progression under the oxaliplatin-based regime in the first-line treatment of $\mathrm{mCRC}$ patients to the literature, though we used retrospective data.

Consequently, we can state that mFOLFIRI-B regime provides a significant survival advantage in secondline treatment of $\mathrm{mCRC}$ patients in whom progression was detected after the oxaliplatin-based regime in the first-line treatment. It provides reduction in the volume and number of the metastatic tumor, makes it easy to metastasectomy, increases PFS and OS and has easly managable side effects. We think that there is a need to make prospective studies for clerance of this topic.

\section{References}

1. Jemal A, Bray F, Center MM, Ferlay J, Ward E, Forman D. Cancer Statistics. CA Cancer J Clin 2011;61(2):69-90.

2. Libutti SK, Saltz LB, Tepper JE. Colon Cancer. In: DeVita, Hellman, And Rosenberg's Cancer: Principles \& Practice of Oncology, DeVita VT, Lawrence TS, Rosenberg SA, Lippincott Williams\&Wilkins, Philadelphia 2008;1232-85.

3. Benjamin RT. Gastrointestinal Cancer. Colorectal And Anal. In: The Washington Manual Of Oncology, Govindan R, Lippincott Williams\&Wilkins, Philadelphia 2008;190-96.

4. O'Neil BH, Goldberg RM. Innovations in chemotherapy for metastatic colorectal cancer: an update of recent clinical trials. Oncologist 2008;13(10):1074-83.

5. Libutti SK, Tepper JE, Saltz LB. Rectal Cancer. In: DeVita, Hellman, And Rosenberg's Cancer: Principles \& Practice of Oncology, DeVita VT, Lawrence TS, Rosenberg SA, Lippincott Williams\&Wilkins, Philadelphia 2008;1285-301.

6. The Meta-Analysis Group in Cancer. Modulation of fluorouracil by leucovorin in patients with advanced colorectal cancer: an updated meta-analysis. J Clin Oncol 2004;22(18):3766-75.

7. Nordic Gastrointestinal Tumor Adjuvant Therapy Group. Expectancy or primary chemotherapy in patients with advanced asymptomatic colorectal cancer: a randomized trial. J Clin Oncol 1992;10(6):904-11.

8. Scheithauer W, Rosen H, Kornek GV, Sebesta C, Depisch D. Randomised comparison of combination chemotherapy plus supportive care with supportive care alone in patients with metastatic colorectal cancer. BMJ 1993;306(6880):752-55.

9. Simmonds PC. Palliative chemotherapy for advanced colorectal cancer: systematic review and meta-analysis. Colorectal Cancer Collaborative Group. BMJ 2000;321(7260):531-35.

10. Cunningham D, Atkin W, Lenz HJ, Lynch HT, Minsky B, Nordlinger B et al. Colorectal cancer. Lancet, 2010;375(9719):1030-47.

11. Grothey A, Sargent D, Goldberg RM, Schmoll HJ. Survival of patients with advanced colorectal cancer improves with the availability of fluorouracil-leucovorin, irinotecan, and oxaliplatin in the course of treatment. J Clin Oncol2004;22(7):1209-14.

12. Kelly H, Goldberg RM. Systemic therapy for metastatic colorectal cancer: current options, current evidence. J Clin Oncol 2005;23(20):4553-60.

13. Hurwitz H, Fehrenbacher L, Novotny W, Cartwright T, Hainsworth J, Heim W, et al. Bevacizumab plus irinotecan, fluorouracil, and leucovorin for metastatic colorectal cancer. $\mathrm{N}$ Engl J Med 2004;350(23):2335-42. 
14. Van Cutsem E, Köhne CH, Hitre E, Zaluski J, Chang Chien $\mathrm{CR}$, Makhson A, et al. Cetuximab and chemotherapy as initial treatment for metastatic colorectal cancer. $N$ Engl J Med 2009;360(14):1408-17.

15. Takahashi S, Nagai K, Saito N, Konishi M, Nakagohri $\mathrm{T}$, Gotohda N, et al. Multiple resections for hepatic and pulmonary metastases of colorectal carcinoma. Jpn J Clin Oncol 2007;37(3):186-92.

16. Van Schaik PM, Kouwenhoven EA, Bolhuis RJ, Biesma B, Bosscha K. Pulmonary resection for metastases from colorectal cancer. J Thorac Oncol 2007;2(7):652-6.

17. Kandioler D, Krömer E, Tüchler H, End A, Müller MR, Wolner E, et al. Long-term results after repeated surgical removal of pulmonary metastases. Ann Thorac Surg 1998;65(4):909-12.

18. Koga R, Yamamoto J, Saiura A, Yamaguchi T, Hata E, Sakamoto M. Surgical resection of pulmonary metastases from colorectal cancer: four favourable prognostic factors. Jpn J Clin Oncol 2006;36(10):643-8.

19. Goodwin RA, Asmis TR. Overview of systemic therapy for colorectal cancer. Clin Colon Rectal Surg 2009;22(4):251-56.

20. Tournigand C, André T, Achille E, Lledo G, Flesh M, MeryMignard D, et al. FOLFIRI followed by FOLFOX6 or the reverse sequence in advanced colorectal cancer: a randomized GERCOR study. J Clin Oncol 2004;22(2):229-37.

21. Colucci G, Gebbia V, Paoletti G, Giuliani F, Caruso M, Gebbia N, et al. Phase III randomized trial of FOLFIRI versus FOLFOX 4 in the treatment of advanced colorectal cancer: a multicenter study of the Gruppo Oncologico Dell'Italia Meridionale. J Clin Oncol 2005;23(22):4866-75.

22. Oukkal M, Djilat K, Hadjam RM, Mahgoun M, Bentabak K, Graba A, et al. Treatment of advanced and/or metastatic colorectal cancer with bevacizumab in combination with oxaliplatin-based chemotherapy (Folfox7 regimen). Bull Cancer 2010;97(4):469-74.

23. Bokemeyer C, Bondarenko I, Hartmann JT, de Braud F, Schuch G, Zubel A, et al. Efficacy according to biomarker status of cetuximab plus FOLFOX-4 as first-line treatment for metastatic colorectal cancer: the OPUS study. Ann Oncol, 2011.

24. Ferrara N, Gerber HP, LeCouter J. The biology of VEGF and its receptors. Nat Med 2003;9(6):669-76.

25. Kabbinavar F, Hurwitz HI, Fehrenbacher L, Meropol NJ, Novotny WF, Lieberman G, et al. Phase II, randomized trial comparing bevacizumab plus fluorouracil (FU)/leucovorin (LV) with FU/LV alone in patients with metastatic colorectal cancer. J Clin Oncol 2003;21(1):60-5.

26. Kabbinavar FF, Schulz J, McCleod M, Patel T, Hamm JT, Hecht $\mathrm{JR}$, et al. Addition of bevacizumab to bolus fluorouracil and leucovorin in first-line metastatic colorectal cancer: results of a randomized phase II trial. J Clin Oncol 2005;23(3):3697-705.

27. Kabbinavar FF, Hambleton J, Mass RD, Hurwitz HI, Bergsland E, Sarkar S. Combined analysis of efficacy: the addition of bevacizumab to fluorouracil/leucovorin improves survival for patients with metastatic colorectal cancer. J Clin Oncol 2005;23(16):3706-12.
28. Fuchs CS, Marshall J, Mitchell E, Wierzbicki R, Ganju V, Jeffery $M$, et al. Randomized, controlled trial of irinotecan plus infusional, bolus, or oral fluoropyrimidines in first-line treatment of metastatic colorectal cancer: results from the BICC-C Study. J Clin Oncol 2007;25(30):4779.

29. The National Comprehensive Cancer Network. Clinical practice guidelines in oncology: colon cancer, version 3; 2012. Available at http://www.nccn.org/professionals/physician gls/ PDF/colon.pdf.

30. American Joint Committee on Cancer (AJCC)(2002)Colon and Rectum. Philadelphia: Lippincott-Raven Publishers.

31. World Health Organization. WHO handbook for reporting results of cancer treatment. http://whqlibdoc. who. int/ publications/9241700483. pdf.

32. National Cancer Institute-Common Toxicity Criteria, Version 2.0; 1999. http://whqlibdoc.who.int/publications/9241700483. pdf.

33. Dy GK, Hobday TJ, Nelson G, Windschitl HE, O'Connell MJ, Alberts SR, et al. Long-term survivors of metastatic colorectal cancer treated with systemic chemotherapy alone: a north central cancer treatment group review of 3811 patients, n0144. Clin Colorectal Cancer 2009;8(2):88-93.

34. Kopetz S, Chang GJ, Overman MJ, Eng C, Sargent DJ, Larson $\mathrm{DW}$ et al. Improved survival in metastatic colorectal cancer is associated with adoption of hepatic resection and improved chemotherapy. J Clin Oncol 2009;1;27(22):3677-83.

35. Van Cutsem E, Rivera F, Berry S, Kretzschmar A, Michael M, DiBartolomeo M, et al. Safety and efficacy of first-line bevacizumab with FOLFOX, XELOX, FOLFIRI and fluoropyrimidines in metastatic colorectal cancer: the BEAT study. Ann Oncol 2009;20(11):1842.

36. Giantonio BJ, Catalano PJ, Meropol NJ, O’Dwyer PJ, Mitchell EP, Alberts SR, et al. Eastern Cooperative Oncology Group Study E3200 Bevacizumab in combination with oxaliplatin, fluorouracil, and leucovorin (FOLFOX4)for previously treated metastatic colorectal cancer: results from the Eastern Cooperative Oncology Group Study E3200. J Clin Oncol 2007;25(12):1539.

37. Moriwaki T, Bando H, Takashima A, Yamazaki K, Esaki T, Yamashita K, et al. Bevacizumab in combination with irinotecan, 5-fluorouracil, and leucovorin (FOLFIRI) in patients with metastatic colorectal cancer who were previously treated with oxaliplatin-containing regimens: a multicenter observational cohort study (TCTG 2nd-BV study). Med Oncol 2011.

38. Grothey A, Sugrue MM, Purdie DM, Dong W, Sargent $\mathrm{D}$, Hedrick E, et al. Bevacizumab beyond first progression is associated with prolonged overall survival in metastatic colorectal cancer: results from a large observational cohort study (BRiTE). J Clin Oncol 2008;26(33):5326. 